\title{
Nitrous oxide and methane fluxes from perturbed and unperturbed boreal forest sites in northern Ontario
}

\author{
C. L. Schiller and D. R. Hastie \\ Department of Chemistry, and Centre for Atmospheric Chemistry, York University, North York, Ontario, Canada
}

\begin{abstract}
Boreal forests cover approximately $11 \%$ of the terrestrial surface of the world or 14.7 million $\mathrm{km}^{2}$ in the circumpolar region of the northern hemisphere. Of this total, approximately one third of these forests are found in Canada. This accounts for on the order of $50 \%$ of the total land area in Canada. A static chamber technique was used to determine the fluxes of nitrous oxide and methane from four Boreal forest sites near Cochrane, Ontario $\left(49^{\circ} 03^{\prime} \mathrm{N}, 80^{\circ} 40^{\prime} \mathrm{W}\right)$, during the summer of 1992. The four sites included a lowland forest, a drained lowland forest, a clear-cut and drained lowland forest, as well as an upland forest. The $\mathrm{N}_{2} \mathrm{O}$ fluxes ranged from an uptake of 7.7 $\mu \mathrm{g}\left(\mathrm{N}_{2} \mathrm{O}\right) / \mathrm{m}^{2} / \mathrm{hr}$ from a drainage ditch to an emission of $3.1 \mu \mathrm{g}\left(\mathrm{N}_{2} \mathrm{O}\right) / \mathrm{m}^{2} / \mathrm{hr}$ from an unvegetated clear-cut region. The $\mathrm{CH}_{4}$ fluxes ranged from an uptake of $23 \mu \mathrm{g}\left(\mathrm{CH}_{4}\right) / \mathrm{m}^{2} / \mathrm{hr}$ from an upland forest site, to an emission of $2900 \mu \mathrm{g}\left(\mathrm{CH}_{4}\right) / \mathrm{m}^{2} / \mathrm{hr}$ from a drainage ditch. Drainage ditches which contained a large amount of algae exhibited large $\mathrm{CH}_{4}$ production and large $\mathrm{N}_{2} \mathrm{O}$ uptake.
\end{abstract}

\section{Introduction}

Nitrous oxide $\left(\mathrm{N}_{2} \mathrm{O}\right)$ and methane $\left(\mathrm{CH}_{4}\right)$ are long-lived radiatively active trace gases that play an important role in atmospheric warming [Ramanthan et al., 1985]. In addition, both $\mathrm{N}_{2} \mathrm{O}$ and $\mathrm{CH}_{4}$ are important in stratospheric chemistry, with $\mathrm{CH}_{4}$ being an important terminator for chlorine atom reactions and $\mathrm{N}_{2} \mathrm{O}$ being the major source of $\mathrm{NO}_{\mathrm{x}}$ [Finlayson-Pitts and Pitts, 1986]. Polar ice core samples have established that the concentration of $\mathrm{N}_{2} \mathrm{O}$ remained relatively constant before the $1800 \mathrm{~s}$, at about $285-289 \mathrm{ppbv}$ [Pearman et al., 1986], but has since increased at a rate of 0.25 to $0.31 \%$ per year to the present concentration of 310 ppbv [Prinn et al., 1990]. The concentration of methane has increased at a rate of between $0.8 \%$ and $1 \%$ per year, more than doubling in the past 200 years, to its current concentration of $1720 \mathrm{ppbv}$ [Intergovernmental Panel on Climate Change(IPPC), 1992]. While the increases in both nitrous oxide and methane mirror human activities, it is difficult to assess the future direction and impact of these changes without understanding the exchange of these gases between the Earth's surface and the atmosphere.

Present-day global budgets for $\mathrm{N}_{2} \mathrm{O}$ contain large uncertainties, the largest being in the fluxes from soils. Of the $22.6 \pm 11 \mathrm{Tg}\left(\mathrm{N}_{2} \mathrm{O}\right)$ emitted each year, $9.4 \pm 4.7 \mathrm{Tg}\left(\mathrm{N}_{2} \mathrm{O}\right)$ are estimated to be emitted from natural soils [Mosier and Schmiel, 1991]. Therefore, over $40 \%$ of the uncertainty in the global fluxes are due to the uncertainty in natural emissions

Similarly, large uncertainties in the global budget for methane are attributed to the uncertainty in the emissions from natural ecosystems, particularly wetlands [e.g., Ehhalt, 1974; 1985; Ehhalt and Schmidt, 1978; Kahlil and Rasmussen, 1984; Cicerone and Oremland, 1988; Roulet et al., 1994; Moore et al., 1994]. Approximately $25 \%$ of $\mathrm{CH}_{4}$ fluxes are attributed to wetlands, of which, an estimated $38 \%$ are boreal forest wetlands.

Boreal forests cover approximately $11 \%$ of the terrestrial surface of the world or 14.7 million $\mathrm{km}^{2}$ in the circumpolar region of the northern hemisphere [Carleton, 1991]. Approximately one third of

Copyright 1996 by the American Geophysical Union

Paper number 96JD01620.

0148-0227/96.JD-01620\$09.00 this is located in Canada, with the remaining two thirds covering the northern parts of Eurasia. The distinguishing climatic features of a boreal forest are the very short summers, very long and cold winters, and low evapotranspiration which is insufficient to evaporate all the precipitation. These regions tend to be very nutrient poor and because of the climatic region, there tends to be a net accumulation of organic matter. This results in forest soils being high in organic matter, low in nutrients and close to water saturated, resulting in large anaerobic zones which are conducive to the production of reduced gases.

Microbial processes are important in both the production and the consumption of $\mathrm{N}_{2} \mathrm{O}$ and $\mathrm{CH}_{4}$ in soils. Nitrous oxide is produced as a by-product in nitrification and denitrification [Robertson and Tiedje, 1987; Davidson, 1991; Davidson, 1992]. Nitrification requires aerobic conditions while denitrification occurs under very low oxygen conditions. Anoxic conditions, such as those found unsaturated soils, allow for the further reduction of $\mathrm{N}_{2} \mathrm{O}$ to $\mathrm{N}_{2}$. The quantity of $\mathrm{N}_{2} \mathrm{O}$ produced or consumed depends on a complicated balance of biological and physical processes. With methane, a similar competition occurs between methanogenisis, which occurs under anaerobic conditions, and methane oxidation which requires oxygen. Therefore with both $\mathrm{N}_{2} \mathrm{O}$ and $\mathrm{CH}_{4}$ a delicate balance exists between production and consumption in soils.

With the net production or consumption of $\mathrm{N}_{2} \mathrm{O}$ and $\mathrm{CH}_{4}$ dependent on a complicated balance of biological and physical processes, it becomes essential, not only to quantify these fluxes, but to also study the effects of disturbances of the natural balances of ecosystems. Disturbances of these ecosystems, such as those associated with clear-cutting or draining, can change the production/consumption balance. Therefore, with the data available on the fluxes of $\mathrm{N}_{2} \mathrm{O}$ and $\mathrm{CH}_{4}$ from an undisturbed boreal forest being limited, it was not only important to quantify these fluxes, but also to study the effects of the anthropogenic modifications of drainage and clear-cutting on the fluxes from these forests.

\section{Experimental}

\section{Site}

The study took place at the Wally Creek Drainage site $\left(49^{\circ} 03^{\prime} \mathrm{N}\right.$, $80^{\circ} 40^{\prime} \mathrm{W}$ ), approximately $30 \mathrm{~km}$ east of Cochrane, Ontario in the northern Clay Section of the boreal forest region of northeastern 
Ontario [Rowe, 1972]. The Wally Creek Drainage site was established in 1984 as a subprogram of the Canada-Ontario Forest Resource Development Agreement to study the effects of forest drainage on the productivity of a Black Spruce Forest. The climatic data for the Cochrane area shows that the area has a continental climate, with cold winters and warm summers [Anon., 1982a,b,c], and a mean annual temperature of $2^{\circ} \mathrm{C}$. The area was dominated by an advanced growth black spruce forest with trees ranging from 50 to 250 years in age. In 1984, approximately $70 \mathrm{~km}$ of ditches, spaced at 40-m intervals, were dug to drain an area of approximately 300 ha [Jeglum, 1991; Sundström, 1992]. In the summer before drainage (1984), the area was classified and mapped according to the Forest Ecosystem Classification (FEC) [Jones et al., 1983] by Arnup [1985]. The main FEC Operational Groups found in the area were OG8, OG11, OG12, and OG14 [Sundström, 1992]. During this field study, three sites $(1,2$, and 3$)$ were located in OG11 type ecosystems and the fourth site was localed on an OGiv (upianù) site, approximateiy i0 $\mathrm{km}$ east of the main Wally Creek Site. The OG11 classification is characterized by a $>96 \%$ Black Spruce tree layer, few herb species, a very poorly drained, 40 to $160 \mathrm{~cm}$ moderately decomposed peat layer, and moderate hummocks of sphagnum and feathermoss with occasional small water filled depressions. The OG10 classification is characterised by a tree layer containing Balsam Poplar, Trembling Aspen, Balsam Fir, Black Spruce, White Spruce, and White Birch. It has a rich herb layer, and the ground surface consists of primarily deciduous litter with sparse moss cover. The organic layer is generally between 5 and $20 \mathrm{~cm}$ thick.

\section{Methodology}

Three sites within theWally Creek Drainage Location (Figure 1) were chosen to represent the natural forest plus two distinct manipulations of that forest. Site 1 was an undisturbed site, site 2, a drained but standing forest, and site 3 , a drained and clear-cut forest. The fourth site was located on a beach ridge approximately $5 \mathrm{~km}$ from site 1 and is outside of the area depicted in Figure 1. At each site, seven bases were cut into the soil at the beginning of the study and these were left in place during the entire study.

A static chamber technique, previously described by Schiller and Hastie [1994], was used to determine the $\mathrm{N}_{2} \mathrm{O}$ and $\mathrm{CH}_{4}$ fluxes. The chamber consisted of a 3-L Plexiglas container which was placed onto a permanent (for the season) $150 \mathrm{~cm}^{2}$ stainless steel base as required. The chambers were shaded on the top with aluminium foil to minimize the heating within the chamber, however, the sides were left partially uncovered to allow for diffuse light to enter the chamber. A rubber septum located in the top of the chamber allowed a sample to be removed via a double headed needle into an evacuated vacutainer (Becton-Dickinson). The vacutainers were precleaned by evacuating to 20 millitorr, filling with ultra high purity helium (99.999\%), then re-evacuated to 20 millitorr. This cleansing method reduced the $\mathrm{CH}_{4}$ and $\mathrm{N}_{2} \mathrm{O}$ residual levels to below the detection limits for these species. Samples were taken within 1 month of evacuation, and tests showed that over this time frame, there was no measurable diffusion into the container nor any increase in residual $\mathrm{CH}_{4}$ or $\mathrm{N}_{2} \mathrm{O}$ levels. Samples were analyzed no more than $\mathbf{2 0}$ days after collection. Ambient air temperatures, relative humidities and soil temperatures were obtained at the beginning and end of each run. Previous static chamber measurements have shown that at low concentrations the increase in the concentration with time is linear [Shepherd et al., 1991] and therefore to minimize the number of analyses, only two air samples were taken from the chamber for each flux determination. Sample collection times ranged from 2 to 24 hours with a median collection time of 3 hours, which allowed for between 2 and 3 runs per day. Logistical constraints restricted sampling to either duplicate or triplicate chambers.

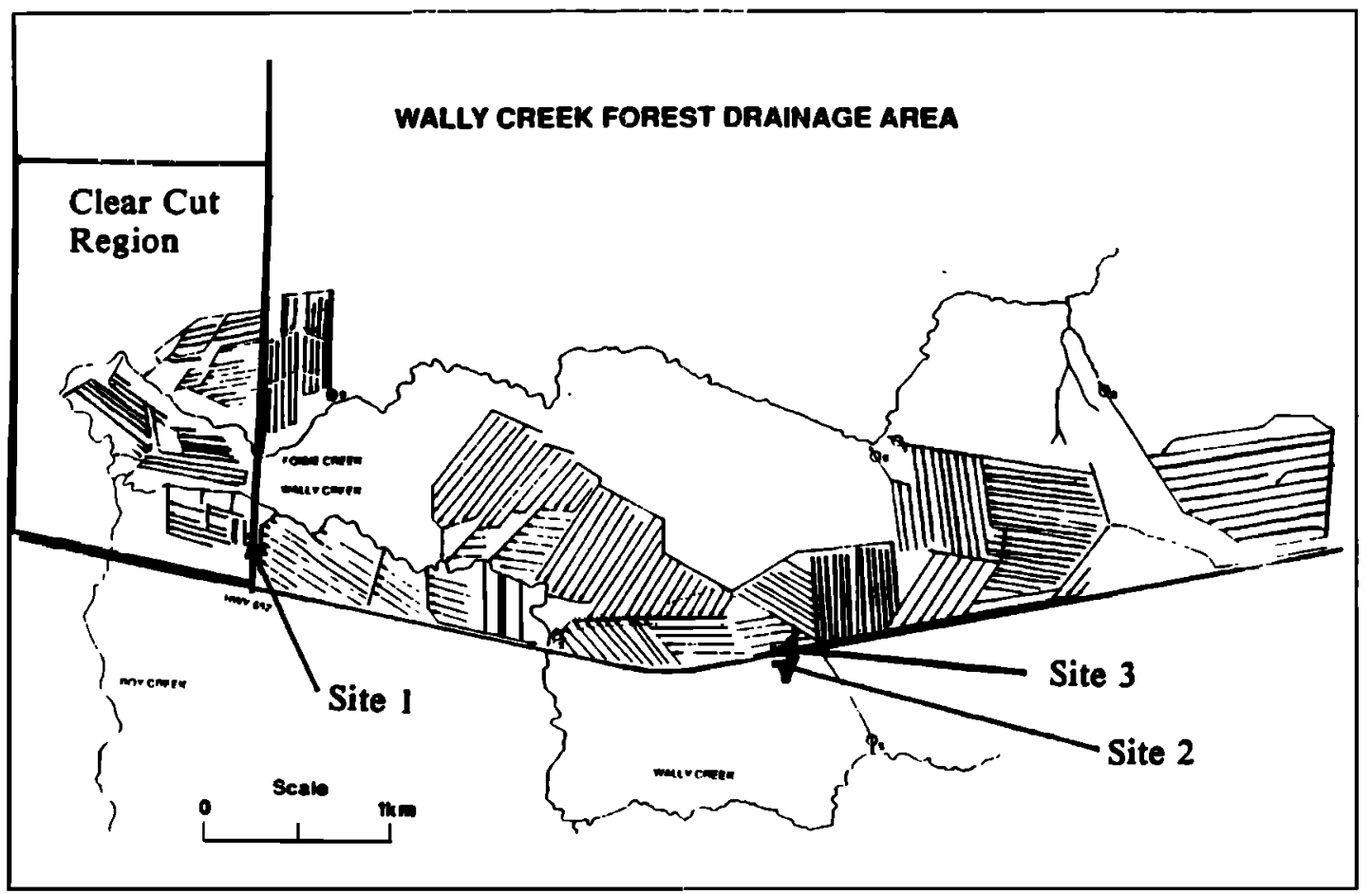

Figure 1. The locations of sites 1, 2, and 3 within the Wally Creek Drainage Area are shown (adapted from Berry and Jeglum [1991]). Site 4, the upland site, was not located within the Wally Creek Drainage Site. The drainage ditches are shown including arrows depicting the direction of flow. The secondary highway 652 seperates the drained and undrained areas. 
There is always concern that the static chamber can underestimate the fluxes from soils due to feedback effects resulting from the placement of the chamber Denmead [1979] and Jury et al.[1982]. However, Jury et al. [1982] found that the lower the air content of the soil, the smaller the effect the chamber had on the measured emission rate. Therefore in a boreal forest, where the water content of the soil is high and the flux rates relatively low, the chamber would be expected to have a minimal effect on the emission rate of $\mathrm{N}_{2} \mathrm{O}$ and $\mathrm{CH}_{4}$, provided the exposure time is such that the gas phase concentrations of these gases remained low.

The $\mathrm{N}_{2} \mathrm{O}$ analysis was performed in the laboratory using an HP 5890 Series II gas chromatograph with an electron capture detector. Samples were analyzed by injecting a $150 \mu \mathrm{L}$ sample, using a Dynatech precision gas sampling syringe with a low volume side port needle, onto a 8-foot x 1/8-inch stainless steel packed column with $45 / 60$ mesh $5 \mathrm{~A}$ molecular sieve maintained at $250^{\circ} \mathrm{C}$. The carrier gas was a mixture of $5 \%$ methane in argon at a flow rate of $30 \mathrm{~mL}$ per minute. The $\mathrm{N}_{2} \mathrm{O}$ peak was eluted at $2 \mathrm{~min}$., well separated from the oxygen and carbon dioxide peaks which eluted before $1 \mathrm{~min}$.. Baseline to baseline integration of the peaks was performed by HP 3365 Chemstation software.

The mixing ratio of $\mathrm{N}_{2} \mathrm{O}$ in a sample was determined by comparison of peak areas with that of a $516 \pm 10$ ppbv $\mathrm{N}_{2} \mathrm{O}$ in $\mathrm{N}_{2}$ standard (Scott Specialty Gases). Eight calibrations were performed for every 20 samples measured. The precision between replicate samples was determined to be better than $2 \%$ in all cases, but generally better than $1 \%$. This resulted in an overall accuracy of better than $3 \%$. For a 2 -hour sample, this results in a minimum detection limit of $0.1 \mu \mathrm{g}\left(\mathrm{N}_{2} \mathrm{O}\right) \mathrm{m}^{-2} \mathrm{hr}^{-1}$.

The $\mathrm{CH}_{4}$ analysis was also performed using an HP 5890 Series II gas chromatograph but with an FID detector at $250^{\circ} \mathrm{C}$. Samples were analysed by injecting a $400-\mu \mathrm{L}$ sample onto a 5-foot $\times 1 / 8$-inch stainless steel column packed with Carbosieve SII maintained at $150^{\circ} \mathrm{C}$. The carrier gas was dry nitrogen at a flow rate of $30 \mathrm{~mL} / \mathrm{min}$, and the $\mathrm{CH}_{4}$ peak was eluted at $1 \mathrm{~min}$. The linearity of the gas chromatograph was determined between 1 to $10 \mathrm{ppm}$ and 10 to 100 ppm. The mixing ratio of $\mathrm{CH}_{4}$ in a sample was determined by comparison of the peak areas with that of a $100.1 \pm 2.0 \mathrm{ppm} \mathrm{CH}_{4}$ in $\mathrm{N}_{2}$ standard (Scott Specialty Gases) which had been dynamically diluted to $8.88 \mathrm{ppm}$. For every 16 samples, 8 standards were run, and the precision between replicate samples was determined to be better than $3 \%$ in all cases. This resulted in an accuracy of better than $3.6 \%$ in all cases which resulted in a minimum detection limit on the order of $2 \mu \mathrm{g}\left(\mathrm{CH}_{4}\right) \mathrm{m}^{-2} \mathrm{hr}^{-1}$ for a 2-hour run. However, since 2 hours was the shortest time period used, the detection limit was better for longer runs, thus $2 \mu \mathrm{g}\left(\mathrm{CH}_{4}\right) \mathrm{m}^{-2} \mathrm{hr}^{-1}$ was the upper limit to the detection limit.

\section{Results and Discussion}

\section{Nitrous Oxide Fluxes from an Undisturbed Boreal Forest Site}

The fluxes of $\mathrm{N}_{2} \mathrm{O}$ from replicate chambers at the undisturbed site in June revealed standard deviations as low as $15 \%$, similar to the results found in a previous study [Schiller and Hastie, 1994]. This indicates that larger deviations between replicate samples at other sites and later in the season were not due to the measurement technique, but likely a result of spatial or temporal variability in the emission fluxes of $\mathrm{N}_{2} \mathrm{O}$ from these ecosystems [Schiller and Hastie, 1994; Bowden et al., 1991; Shepherd et al., 1991; Cates and Keeney, 1987; Goodroad et al., 1984]. Figure 2 shows the fluxes of $\mathrm{N}_{2} \mathrm{O}$ from site 1 , the undisturbed site, as a function of the day of the year. Although the agreement between some replicate samples at the control site were within $15 \%$, close to an order of magnitude difference separated other replicate samples.

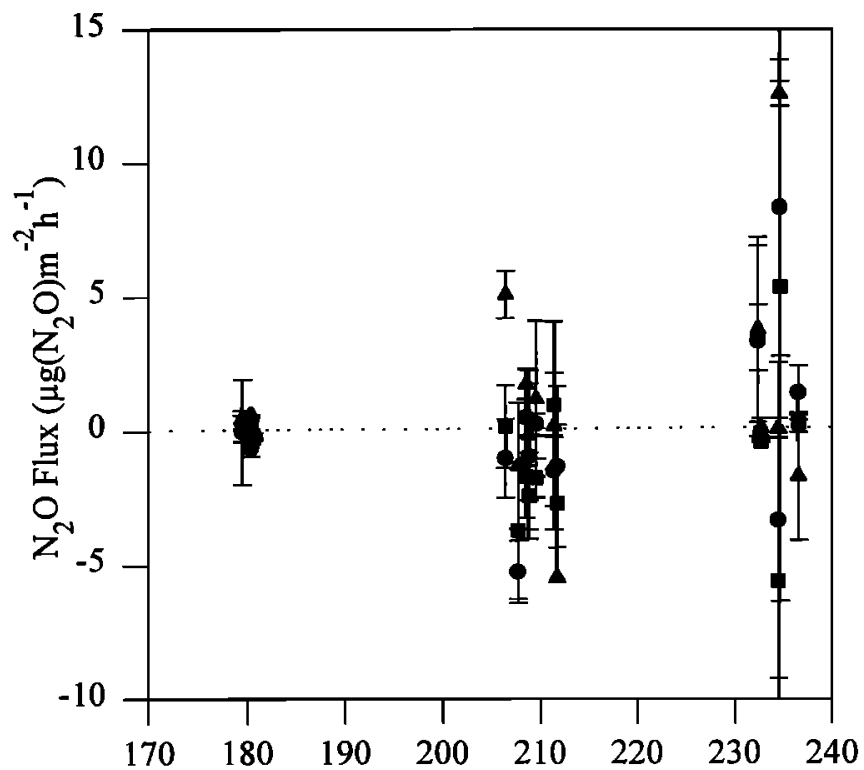

Day of the Year

Figure 2. The fluxes of $\mathrm{N}_{2} \mathrm{O}$ from the (squares) moss hollows, (circles) hummocks, and (triangles) flats at the unperturbed site (site 1) in the boreal forest and a function of the day of the year. The bars represent the standardard deviation between replicate chambers.

With data available for only June, July, and August, an examination of the seasonal variation was not possible. Results from the Northern Wetland Study [Schiller and Hastie, 1994] showed that there could be significant fluxes occurring in late August and early September, although the early seasonal fluxes before June were likely smail. However, the fluxes in June were significantly lower than the fluxes in July and August at all sites (Table 1 and Figure 2). All sites showed both uptake and emission of $\mathrm{N}_{2} \mathrm{O}$ at various times throughout the study. In addition, day-to-day variations in the fluxes were dependent upon the time of year of the measurements. Those measured in June from site 1 were not only lower in magnitude, but showed little spatial or temporal variation, ranging from -0.61 to 0.56 $\mu \mathrm{g}\left(\mathrm{N}_{2} \mathrm{O}\right) \mathrm{m}^{-2} \mathrm{hr} r^{-1}$, with an average flux of $0.03 \pm 0.35 \mu \mathrm{g}\left(\mathrm{N}_{2} \mathrm{O}\right) \mathrm{m}^{-2} \mathrm{hr}^{-1}$. A much larger variability was observed in the July and August data whose average fluxes were $0.15 \pm 2.17 \mu \mathrm{g}\left(\mathrm{N}_{2} \mathrm{O}\right) \mathrm{m}^{-2} \mathrm{hr}^{-1}$ and $1.81 \pm$ $4.29 \mu \mathrm{g}\left(\mathrm{N}_{2} \mathrm{O}\right) \mathrm{m}^{-2} \mathrm{hr}^{-1}$ respectively. On August 22, day 234 (Figure 2), a large change in the flux was observed within the same day, increasing from $-2.96 \pm 2.35 \mu \mathrm{g}\left(\mathrm{N}_{2} \mathrm{O}\right) \mathrm{m}^{-2} \mathrm{hr}^{-1}$ in the morning to 8.73 $\pm 2.97 \mu \mathrm{g}\left(\mathrm{N}_{2} \mathrm{O}\right) \mathrm{m}^{-2} \mathrm{hr}^{-1}$ in the afternoon. This indicates that in this case, the dominant parameter affecting the emission rate must be able to change rapidly with time such as temperature or solar radiation. This probably rules out parameters such as microbial population which require larger timescales for change.

Nitrous oxide emission fluxes measured at site 1, the undisturbed boreal forest site, were divided into those from three topographies, moss hummocks, hollows, and flats (Figure 2). The August results, on an expanded scale are shown in Figure 3. It can be seen that the changes in the $\mathrm{N}_{2} \mathrm{O}$ emission fluxes from these differing topographies were consistent throughout the site and thus independent of the topographic features. Although the water table was not measured during the study, the Wally Creek Drainage area is a hydrologically well-characterized site with the water table at $35 \mathrm{~cm}$ below the peat surface in 1987, 1988, and 1989 [Berry and Jeglum, 1991]. With the water table near the surface ( $<35 \mathrm{~cm}$ depth) and the peat saturated to near the surface, the anaerobic zone would be similar for the 
Table 1. The Fluxes of $\mathrm{N}_{2} \mathrm{O}$ in $\mu \mathrm{g}\left(\mathrm{N}_{2} \mathrm{O}\right) \mathrm{m}^{-2} \mathrm{hr}^{-1}$ from the Four Sites in the Boreal Forest Near Cochrane, Ontario, During June, July, and August of 1992.

\begin{tabular}{|c|c|c|c|c|c|c|c|}
\hline Site & Description & $\begin{array}{c}\mathbf{N}_{2} \mathbf{O} \text { Flux } \\
\text { June }\end{array}$ & $N$ & $\begin{array}{c}\mathbf{N}_{\mathbf{2}} \mathbf{O} \text { Flux } \\
\text { July }\end{array}$ & $N$ & $\begin{array}{c}\mathrm{N}_{2} \mathrm{O} \text { Flux } \\
\text { August }\end{array}$ & $N$ \\
\hline \multirow[t]{4}{*}{1} & Undisturbed Sit & & & & & & \\
\hline & Moss flats & $0.28 \pm 0.32$ & 6 & $0.17 \pm 2.96$ & 14 & $2.96 \pm 5.12$ & 10 \\
\hline & Moss hollows & $-0.26 \pm 0.26$ & 6 & $-1.33 \pm 1.75$ & 14 & $1.88 \pm 3.89$ & 10 \\
\hline & Moss hummocks & $0.05 \pm 0.23$ & 6 & $1.61 \pm 1.52$ & 14 & $0.60 \pm 3.75$ & 10 \\
\hline \multirow[t]{4}{*}{2} & Drained Site & & & & & & \\
\hline & Moss hummocks & $0.31 \pm 0.40$ & 6 & $-0.31 \pm 2.68$ & 12 & $-0.19 \pm 0.52$ & 18 \\
\hline & Moss hollows & $0.64 \pm 0.99$ & 6 & $2.10 \pm 1.80$ & 8 & $0.08 \pm 0.62$ & 12 \\
\hline & Drainage ditch & $-0.06 \pm 0.76$ & 6 & $0.18 \pm 2.91$ & 8 & $0.06 \pm 0.71$ & 12 \\
\hline \multirow[t]{5}{*}{3} & Clear-Cut Drained & & & & & & \\
\hline & Vegetated & $0.06 \pm 038$ & 14 & $-011 \pm 2.27$ & 12 & $-052 \pm 0.59$ & 8 \\
\hline & Unvegetated & $3.13 \pm 4.68$ & 14 & $2.61 \pm 1.10$ & 12 & $0.41 \pm 0.35$ & 10 \\
\hline & Drainage ditch 1 & $-0.64 \pm 0.25$ & 6 & $-7.34 \pm 6.66$ & 6 & $-1.21 \pm 0.98$ & 5 \\
\hline & Drainage ditch 2 & $-1.44 \pm 1.14$ & 7 & $-8.02 \pm 8.42$ & 6 & $-1.11 \pm 0.45$ & 5 \\
\hline \multirow[t]{4}{*}{4} & Upland Forest $S i$ & & & & & & \\
\hline & Light shrub area & $-0.42 \pm 0.77$ & 12 & $2.85 \pm 2.39$ & 10 & $-0.05 \pm 0.11$ & 6 \\
\hline & Heavy shrub area & $0.20 \pm 0.68$ & 12 & $0.99 \pm 1.07$ & 10 & $0.28 \pm 0.54$ & 6 \\
\hline & Forest edge & $-0.36 \pm 0.91$ & 12 & $1.65 \pm 1.36$ & 10 & $0.47 \pm 0.50$ & 6 \\
\hline
\end{tabular}

The error given is the standard deviation from all chambers throughout the given month. The value of $N$ represents the total sample number.

hummocks, hollows, and flats. Therefore the fluxes from the hummocks, hollows, and flats would not be expected to differ significantly, which was consistent with our results.

Figure 4 shows the fluxes of $\mathrm{N}_{2} \mathrm{O}$ as a function of soil temperature and no clear effect of temperature on the flux was observed, although,

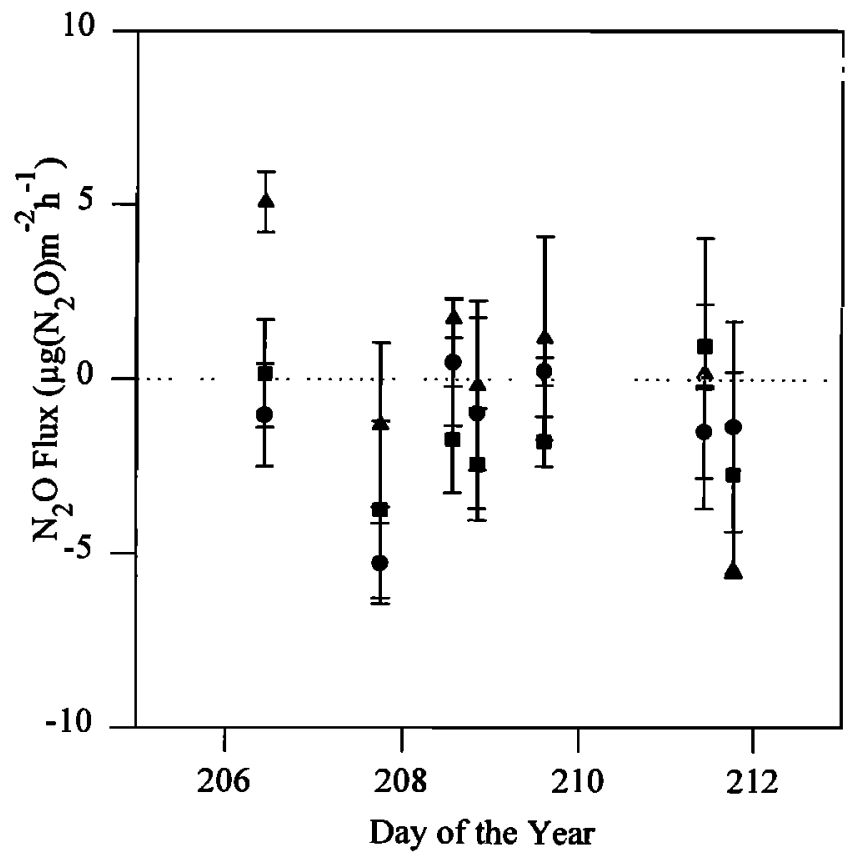

Figure 3. The fluxes of $\mathrm{N}_{2} \mathrm{O}$ from (circles) moss hollows, (squares) hollows, and (triangles) flats at the unperturbed site (site 1) as a function of the day of the year in the month of July. The bars represent the standardard deviation between replicate chambers. half of the sites exhibited a $\mathrm{N}_{2} \mathrm{O}$ flux maximum near $12^{\circ} \mathrm{C}$. The fluxes of $\mathrm{N}_{2} \mathrm{O}$ from the northern wetlands showed a similar pattern, with the maximum occurring near $15^{\circ} \mathrm{C}$ [Schiller, 1994]. This temperature coincided with the mean July air temperature in this region. In the boreal forest, the soil temperature would be expected to be lower than

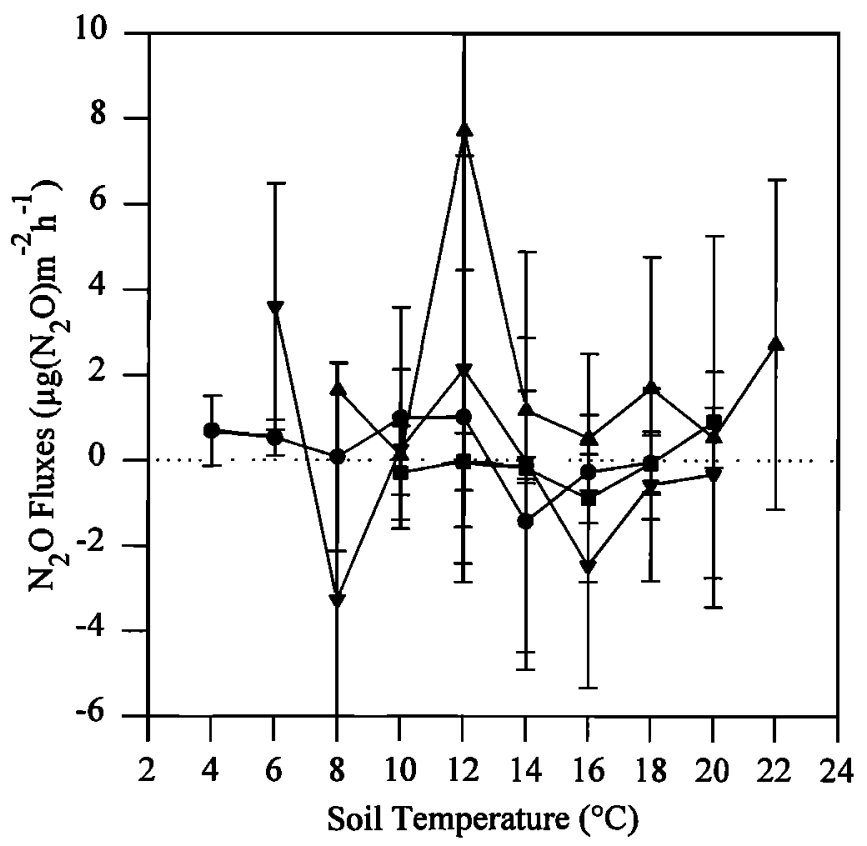

Figure 4. The fluxes of $\mathrm{N}_{2} \mathrm{O}$ from (inverted triangles) site 1, (circles) site 2, (squares) the vegetated portion of site 3 and (triangles) the unvegetated portion of site 3 as a function of the soil temperature (excluding emissions from ditches). The fluxes have been binned into $2^{\circ} \mathrm{C}$ increments and the bars represent the standard deviation of these fluxes. 
the ambient temperatures due to shading, therefore a maximum at $12^{\circ} \mathrm{C}$ in a region were the ambient mean is $15^{\circ} \mathrm{C}$ may be feasible. This could indicated that these maxima were real and were due to the adaptation of the microbes to the soil temperature in the region.

The upland site, primarily deciduous, (site 4) was divided into three areas, light shrubs, heavy shrubs, and an edge of the forest site. The edge site was next to a small clearing and thus received a much larger amount of sunlight than the other two areas. There was no significant difference in the emission fluxes from each of these areas, nor were the fluxes from this site significantly different from those at the undisturbed boreal site (site 1). Thus the error in the total $\mathrm{N}_{2} \mathrm{O}$ fluxes from boreal forests would be small if the upland sites were estimated to have the same fluxes as the majority of the boreal forest.

The monthly averages of the $\mathrm{N}_{2} \mathrm{O}$ exchange rates from all sites at the boreal forest are collected in Table 1. The standard deviations in the monthly averages include both the temporal and seasonal variations in each ecosystem. All sites exhibited both uptake and fluxes.

\section{Methane Fluxes from an Undisturbed Boreal Forest Site}

The $\mathrm{CH}_{4}$ fluxes from different topographical classifications, within the undisturbed site, were examined. Fluxes from hummocks, hollows, and flats were found to be not significantly different at this site. All topographies showed similar uptake and emission occurring throughout the summer (Figure 5). This result was similar to that found for nitrous oxide, where the differences could not be explained by topographic differences. This was likely due to the near saturation conditions to the surface resulting in similarly small aerobic zones in all three topographical regions.

The upland forest site exhibited either very low fluxes or uptake of $\mathrm{CH}_{4}$ throughout the measurement campaign. The highest average fluxes were observed at the forest edge, although due to the large

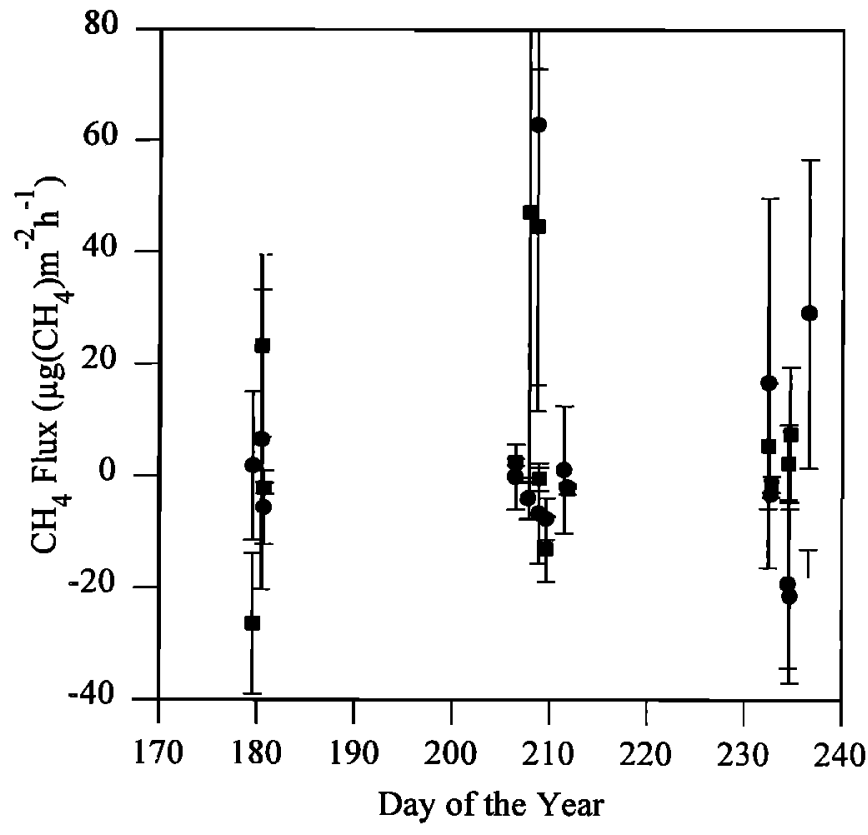

Figure 5. The fluxes of methane as a function of the day of the year from (circles) the hummocks, and (squares) hollows at the unperturbed site (site 1) in the boreal forest. The bars indicate the standard deviation between replicate chambers

spatial variability observed and relatively small sample size, this site was statistically no higher than within deep within the forest. The heavy shrub area, which best represented this site, exhibited net uptake throughout June, July and August. The largest uptake occurred in August from all sites (Table 2). Steudler et al. [1989] observed net uptake of $\mathrm{CH}_{4}$ from temperate forest soils in

Table 2. The Fluxes of $\mathrm{CH}_{4}$ in $\mu \mathrm{g}\left(\mathrm{CH}_{4}\right) \mathrm{m}^{-2} \mathrm{hr}^{-1}$ From the Four Sites in the Boreal Forest Near Cochrane, Ontario, During June, July and August of 1992.

\begin{tabular}{|c|c|c|c|c|c|c|c|}
\hline Site & Description & $\underset{\substack{\text { June } \\
\mathrm{CH}_{4} \text { Flux }}}{ }$ & $N$ & $\begin{array}{c}\mathrm{CH}_{\mathbf{4}} \text { Flux } \\
\text { July }\end{array}$ & $N$ & $\begin{array}{c}\mathrm{CH}_{4} \text { Flux } \\
\text { August } \\
\end{array}$ & $N$ \\
\hline \multirow[t]{4}{*}{1} & Undisturbed Si & & & & & & \\
\hline & Moss Flats & $1 \pm 5$ & 6 & $6 \pm 23$ & 14 & $1 \pm 20$ & 10 \\
\hline & Moss Hollows & $-2 \pm 20$ & 6 & $11 \pm 23$ & 14 & $0 \pm 8$ & 10 \\
\hline & Moss Hummocks & $-9 \pm 7$ & 6 & $3 \pm 7$ & 14 & $-18 \pm 31$ & 10 \\
\hline \multirow[t]{4}{*}{2} & Drained Site & & & & & & \\
\hline & Moss Hummocks & $8 \pm 25$ & 6 & $-17 \pm 17$ & 12 & $-15 \pm 8$ & 18 \\
\hline & Moss Hollows & $-9 \pm 11$ & 6 & $28 \pm 22$ & 8 & $7 \pm 16$ & 12 \\
\hline & Drainage Ditch & $-41 \pm 10$ & 6 & $83 \pm 62$ & 8 & $2 \pm 21$ & 12 \\
\hline \multirow[t]{5}{*}{3} & Clear-cut Drained & & & & & & \\
\hline & Vegetated & $12 \pm 34$ & 14 & $-22 \pm 31$ & 12 & $8 \pm 8$ & 8 \\
\hline & Unvegetated & $6 \pm 23$ & 14 & $-1 \pm 41$ & 12 & $-9 \pm 19$ & 10 \\
\hline & Drainage Ditch 1 & $-51 \pm 73$ & 6 & $21 \pm 21$ & 6 & $1 \pm 21$ & 5 \\
\hline & Drainage Ditch 2 & $522 \pm 636$ & 7 & $1430 \pm 804$ & 6 & $2920 \pm 2380$ & 5 \\
\hline \multirow[t]{4}{*}{4} & Upland Forest $S$ & & & & & & \\
\hline & Light Shrub Area & $6 \pm 14$ & 12 & $8 \pm 19$ & 10 & $-11 \pm 9$ & 6 \\
\hline & Heavy Shrub Area & $-13 \pm 14$ & 12 & $3 \pm 11$ & 10 & $-23 \pm 17$ & 6 \\
\hline & Forest Edge & $-14 \pm 23$ & 12 & $-1 \pm 13$ & 10 & $-14 \pm 10$ & 6 \\
\hline
\end{tabular}

The error given is the standard deviation from all chambers throughout the given month. The total sample number is given as $N$. 
Massachusetts of $3.17 \mathrm{mg} \mathrm{CH}_{4}-\mathrm{C} \mathrm{m}^{-2} \mathrm{~d}^{-1}$ or $176 \mu \mathrm{g}\left(\mathrm{CH}_{4}\right) \mathrm{m}^{-2} \mathrm{hr} r^{-1}$. This uptake is considerably higher than the maximum of $23 \mu \mathrm{g}\left(\mathrm{CH}_{4}\right) \mathrm{m}^{-2} \mathrm{hr}^{-1}$ observed at the upland site. These results agree with those of Steudler et al. [1989], showing that upland (deciduous) forest sites are likely small sinks for tropospheric methane.

The monthly averages for the emission or uptake of $\mathrm{CH}_{4}$ are shown in Table 2. It should be noted that the standard deviation represents not only the spatial variability but the temporal variability, including diurnal variability, of the emission rates at the sites. With only 3 to 4 measurements from an individual site available during any one day, a diurnal pattern could not be quantitatively determined. Qualitatively, the exchange of $\mathrm{CH}_{4}$, as either an uptake or an emission, tended to be larger in the middle of the day, while those in early morning or late evening approached zero. Night measurements were not available during this field study due to logistical constraints.

In general, fluxes from the undisturbed sites were relatively low throughout the sludy, wiih̀ a maximum finux of $\mathrm{i} i \pm \hat{2} 3 \mu \mathrm{g}\left(\mathrm{CH}_{4}\right) \mathrm{m}^{-2} \mathrm{hr}^{-1}$ occurring in July. These measurements were much lower than the 1.8 $\pm 0.8 \mathrm{mg}\left(\mathrm{CH}_{4}\right) \mathrm{m}^{-2} \mathrm{~d}^{-1}$ or $75 \mu \mathrm{g}\left(\mathrm{CH}_{4}\right) \mathrm{m}^{-2} \mathrm{hr} r^{-1}$ observed from the treed bog sites in the Hudson Bay Lowland by Roulet et al. [1994]. The boreal forest near Cochrane, Ontario has a lower water table, and therefore a larger aerobic zone, which may account for the lower fluxes from this site.

\section{The Effects of Drainage on the Emission Rate of $\mathrm{N}_{2} \mathrm{O}$ and $\mathrm{CH}_{4}$}

As stated above, examination of the variability of the $\mathrm{N}_{2} \mathrm{O}$ fluxes at the undisturbed site (Figure 2) showed no significant difference in the emission flux for $\mathrm{N}_{2} \mathrm{O}$ from hummocks, hollows, or flats. This result was expected, since there was no difference in the water content of the surface peat under these distinct topographic areas. However, with the addition of drainage ditches, the water level was lowered and one would expect the emission flux of $\mathrm{N}_{2} \mathrm{O}$ to decrease, due to the increased aerobic zone. Table 2 contains the mean emission flux of $\mathrm{N}_{2} \mathrm{O}$ for June, July, and August at the drained standing forest site(site 2). The fluxes from this site were indistinguishable from those obtained from the undisturbed site (site 1). In addition, there was no significant difference in the emission fluxes from the drainage ditches than from the hummocks or hollows. Therefore the addition of drainage ditches shows no clear effect on the fluxes of $\mathrm{N}_{2} \mathrm{O}$.

Similarly, methane showed no significant difference in the fluxes from hummocks, hollows, and flats at the undisturbed site. With the lowered water table and thus an increased aerobic zone at the drained site, fluxes from hummocks would be expected to be lower than those from hollows. Statistics indicate that although fluxes of $\mathrm{CH}_{4}$ from the hummocks and the hollows were not significantly different in June, in July and August the fluxes from the hollows were statistically higher than those from the hummocks (Table 2). The hummocks showed uptake of $\mathrm{CH}_{4}$, while the hollows showed emission.

Emission from the drainage ditches at the drained site (site 2) followed a pattern similar to that of the hollows. In June the ditches showed a net uptake significantly higher than those by the hollows and hummocks. However, in July and August the drainage ditches exhibited a net emission of $\mathrm{CH}_{4}$ not significantly different from the fluxes from the hollows, but significantly higher than the fluxes from the hummocks (Table 2).

\section{Effects of Clear-Cutting on the Emission of $\mathrm{N}_{2} \mathrm{O}$ and $\mathrm{CH}_{4}$}

Site 3 was drained and clear-cut in 1985 and consisted of widely dispersed new growth trees, generally less than $2 \mathrm{~m}$ in height. The long-term effects of clear-cutting on the emission of $\mathrm{N}_{2} \mathrm{O}$ and $\mathrm{CH}_{4}$

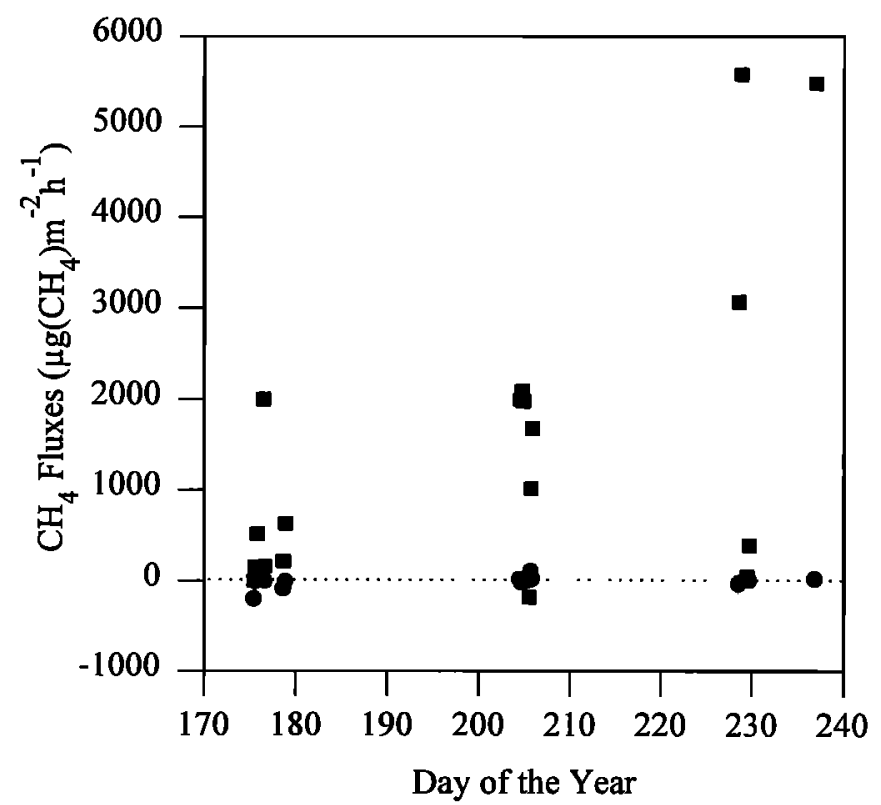

Figure 6. The fluxes of $\mathrm{CH}_{4}$ as a function of the day of the year from (circles) ditch one, little algal growth and (squares) ditch two, large algal growth at the clear-cut drained site (site 3 ) in the boreal forest.

can be seen in Tables 1 and 2 by a comparison of the undisturbed site (site 1) versus those from the clear-cut site (site 3). One of the side effects of the clear-cutting was the destruction of the surface moss layer, so this effect was considered as an effect of clear-cutting and is discussed in this section. In addition, the drainage ditches in the clearcut and drained region exhibited different behavior from those at the drained area alone. The difference was attributed to the greater solar radiation irradiating the ditches in the clear-cut site.

The emission fluxes of $\mathrm{CH}_{4}$ in the vegetated and unvegetated areas of the clear-cut drained site (site 3) were not significantly different, nor were they significantly different from those at the undisturbed site (Table 2). A similar result was observed for the vegetated region at the clear-cut site compared to those from undisturbed site during June and July, although the August fluxes were significantly smaller at the clear-cut site. However, the unvegetated area showed significantly higher $\mathrm{N}_{2} \mathrm{O}$ fluxes than the vegetated regions (Table 1). These results suggest that the lack of surface vegetation does not significantly change the aerobic and anaerobic zones in the peat, thus producing no changes in the fluxes of $\mathrm{CH}_{4}$. However, the increase in the $\mathrm{N}_{2} \mathrm{O}$ fluxes could be due to an increase in nitrification very close to the surface rather than an increase in denitrification rates. This result was consistent with $\mathrm{NO}_{\mathrm{x}}$ emission measurements which revealed higher emission fluxes from these unvegetated regions [Schiller, 1994].

The drainage ditches at site 3 , the clear-cut drained site, consistently showed a net uptake of $\mathrm{N}_{2} \mathrm{O}$. There was no significant difference in the average monthly uptake of $\mathrm{N}_{2} \mathrm{O}$ from the two ditches studied. The uptake from these drainage ditches was larger than from the drainage ditches located at the drained but forested sites (site 2). This exchange of $\mathrm{N}_{2} \mathrm{O}$ from the drainage ditches was also significantly different from that observed at the vegetated and unvegetated regions at this site. This uptake of $\mathrm{N}_{2} \mathrm{O}$ was thought to be influenced by the growth of algae in the ditch, although the exact relationship was not determined.

Methane fluxes were also measured from two sections of a drainage ditch at the clear-cut drained site (site 3). Both showed large uptakes with those from ditch two being as much as 3 orders of magnitude higher than from ditch one (Figure 6). Both ditches 
showed evidence of algal growth; however, there was much more in ditch two. Although draining a wetland would be expected to decrease the $\mathrm{CH}_{4}$ emission fluxes, due to the increased aerobic zone, the large fluxes of $\mathrm{CH}_{4}$ from drainage ditches may well compensate for this decrease. These fluxes could be further increased by large algal growth in the drainage ditches. In addition, it is possible that the algae can utilize nitrous oxide in its nitrogen fixing process, thus causing the large $\mathrm{N}_{2} \mathrm{O}$ uptakes observed.

\section{Conclusions}

The fluxes of nitrous oxide were generally low from all sites, with all sites exhibiting both uptake and fluxes. These values ranged from an uptake of $7.7 \mu \mathrm{g}\left(\mathrm{N}_{2} \mathrm{O}\right) \mathrm{m}^{-2} \mathrm{hr}^{-1}$ to an emission of $3.1 \mu \mathrm{g}\left(\mathrm{N}_{2} \mathrm{O}\right) \mathrm{m}^{-2}$ $\mathrm{hr}^{-1}$. Drainage alone did not cause any significant increase in the fluxes of $\mathrm{N}_{2} \mathrm{O}$, however, the unvegetated regions at the clear-cut and drained site exhibited the largest fluxes of $\mathrm{N}_{2} \mathrm{O}$. These higher fluxes in the unvegetated regions compared to the vegetated regions were likely caused by an increase in nitrification at the surface. The largest uptake occurred in the drainage ditches located at the clear-cut drained site, and algal growth likely played a major role in these higher uptake rates.

The fluxes of methane from the undisturbed site were relatively low throughout the study with the maximum emission flux of $11 \pm 23$ $\mu \mathrm{g}\left(\mathrm{CH}_{4}\right) \mathrm{m}^{-2} \mathrm{hr} \mathrm{r}^{-1}$ being less than $15 \%$ of the $75 \mu \mathrm{g}\left(\mathrm{CH}_{4}\right) \mathrm{m}^{-2} \mathrm{hr}^{-1}$ measured by Roulet et al., [1994] in the treed bog sites of the Hudson Bay Lowland. Drainage of a boreal forest site, which caused a lowering of the water table, resulted in hummocks producing lower fluxes than hollows. The largest fluxes of methane were observed from drainage ditches in the clear-cut and drained site. These fluxes were as much as 3 orders of magnitude higher than the fluxes from the area between the ditches. These larger fluxes appeared to be associated with the presence of algae growing within the ditches, although the exact relationship was not investigated. Therefore, although the drainage ditches occupy a relatively small surface area, those that contain algae could be a significant source of methane.

Acknowledgments. We would like to thank J.K. Jeglum of Forestry Canada for access to the Wally Creek Drainage site and the use of facilities near the site. We would also like to thank J.K. Jeglum and Paul Adams of Forestry Canada, Ontario Region, for their informative discussions and support during this study. We would also like to thank Nigel Roulet for his invaluable discussions. This work has been generously supported by the Natural Sciences and Engineering Research Council of Canada.

\section{References}

Anon., Canadian climate normals (1951-1980), vol. 2, Temperature, pp. 186, Environ. Can, Atmos. Environ. Serv., Downsview, Ont., 1982a.

Anon., Canadian climate normals (1951-1980), vol. 3, Precipitation, pp. 602, Environ. Can, Atmos. Environ. Serv., Downsview, Ont., $1982 b$.

Anon., Canadian climate normals (1951-1980), vol. 4, Degree-Days, pp 280, Environ. Can, Atmos. Environ. Serv., Downsview, Ont., $1982 \mathrm{c}$.

Amup, R., Land resources surveys: Peatland forest drainage project, Wally Creek area. Rep. by Ecological Services for Planning Ltd., for Ont. Min. Nat. Resour., Timmins, Ont., 1985.

Berry, G.J., and J.K. Jeglum, Hydrology of drained and undrained black spruce peatlands: Surface water and groundwater quality, COFRDA Rep. 3316, For. Can., Ont. Region, Sault Ste. Marie, Ont., 1991.

Bowden, R.D., J.M. Melillo, P.A. Steudler, and J.D. Aber, Effects of nitrogen addition on annual nitrous oxide fluxes from temperate forest soils in the northeastern United States, J. Geophys. Res., 96, 9321-9328, 1991.

Carleton, T., Ecology of the boreal forest: Overview, boreal forest conference proceedings, edited by Joan Sherman, Athabasca University, Athabasca, Alberta, Canada, 1991.

Cates, R.L., and D.R. Keeney, Nitrous oxide emission from native and reestablished prairies in southern Wisconsin, Am. Midland Natualist, 117, 35-42, 1987.

Cicerone, R.J., and R. Oremland, Biogeochemical aspects of atmospheric methane, Global Biogeochem. Cycles, 2, 299-328, 1988.

Davidson, E.A. Fluxes of nitrous oxide and nitric oxide from terrestrial ecosystems, in Microbial Production and Consumption of Greenhouse Gases: Methane, Nitrous Oxides and Halomethanes, edited by J.E. Rogers and W.B. Witman, pp. 219235, Am. Soc. Microbiol., Washington, D.C., 1991.

Davidson, E.A., Sources of Nitrous Oxide following wetting of Dry Soils, Soil Sci. Soc. Am. J., 56, 95-102, 1992.

Denmead, O.T., Chamber systems for measuring nitrous oxide emissions from soils in the field, Soil Sci. Soc. Am. J., 43, 89-95, 1979.

Ehhalt, D.H., The atmospheric cycle of methane, Tellus, 26, 58-70, 1974.

Ehhalt, D.H., and U. Schmidt, Sources and sinks of atmospheric methane, Pure Appl. Geophys., 116, 452-464, 1978.

Finlayson-Pitts, B.J. and J.N. Pitts, Jr., Atmospheric chemistry: Fundamentals and experimental techniques, Wiley-Intersci., New York, 1986

Goodroad, L.L., and D.R. Keeney, Nitrous oxide emission from forest, marsh, and prairie ecosystems, J. Environ. Qual., 13, 448452, 1984.

Goodroad, L.L., D.R. Keeney, and L.A. Peterson, Nitrous oxide emissions from forest, marsh, and prairie ecosystems, J. Environ. Qual., 13, 557-561, 1984.

International Panel on Climate Change (IPCC), Climate Change, The supplementary report to the IPCC Scientific Assessment, edited by J.T. Houghton, B.A. Chandler, and S.K. Varney, Cambridge Univ. Press, New York, 1992.

Jeglum, J.K., 1991, The Wally Creek Drainage Project in Ontario's Clay Belt: Progress Rep., Ont. File Rep., For. Can., Ont. Reg., Sault Ste. Marie, Ont., 1991.

Jones, R.K., G. Pierport, G.M. Wickware, J.K. Jeglum, R.P. Arnup, and J.M. Bowles, Field guide to forest ecosystem classification for the Clay Beli, Site Region 3E, Ont. Min. Nat. Resour., Maple, Ont., 1983.

Jury, W.A., J. Letey, and T. Collins, Analysis of chamber methods used for measuring nitrous oxide production in the field, Soil Sci. Soc. Am. J., 46, 250-256, 1982.

Khalil, M.A.K., and R. Rasmussen, Variability of methane and carbon monoxide at the South Pole, Antarct. J. U. S., 19, 204-206, 1984.

Moore, T.R., A. Hayes and N. T. Roulet, Methane Emissions from wetlands, southem Hudson Bay lowland, J. Geophys. Res., 99, 1455-1467, 1994.

Mosier, A.R., and D.S. Schimel, Influence of agricultural nitrogen on atmospheric methane and nitrous oxide, Chem. Ind., 23, 874-877, 1991.

Pearman, G.J., D. Etheridge, F. de Silva, and P.J. Fraser, Evidence of changing concentrations of atmospheric $\mathrm{CO}, \mathrm{N}_{2} \mathrm{O}$ and $\mathrm{CH}_{4}$ from air bubbles in Antarctic ice, Nature, 320, 248- 250, 1986.

Prinn, R., D. Cunnold, R. Rasmussen, P. Simmonds, F. Alyea, A. Crawford, P. Fraser, and R. Rosen, Atmospheric emissions and trends of nitrous oxide deduced from 10 years of ALE-GAGE Data, J. Geophys. Res., 95, 18,369-18,385, 1990.

Ramanathan, V., R.J. Cicerone, H.B. Singh, and J.T. Kiehl, Trace gas trends and their potential role in climate change, J. Geophys. Res., 90, 5547-5566, 1985.

Robertson, G.P. and J.M. Tiedje, Nitrous oxide sources in aerobic soils: Nitrification, denitrification and other biological processes, Soil Biol. Biochem., 19, 187-193, 1987.

Rowe, J.S., Forest regions in Canada., Publ. 1300, Dep. Environ., Can. For. Serv., Ottawa, Ont., 1972.

Roulet, N.T., A. Jano, C.A. Kelly, L. Klinger, T.A. Moore, R. Protz J. Ritter, and W.R. Rouse, The role of the Hudson Bay Lowland as a source of atmospheric methane, J. Geophys. Res., 99,1439-1454, 1994. 
Schiller, C.L., and D.R. Hastie, Exchange of nitrous oxide within the Hudson Bay lowland, J. Geophys. Res., 99, 1573-1588, 1994.

Schiller, C.L., Soil emission inventories of $\mathrm{NO}_{x}$ and $\mathrm{N}_{2} \mathrm{O}$ from Natural Ecosystems in Ontario, Ph. D. Thesis, York University, North York, Ont., Canada, 1994.

Shepherd, M.F., S. Barzetti, and D.R. Hastie, The production of atmospheric $\mathrm{NO}_{\mathrm{x}}$ and $\mathrm{N}_{2} \mathrm{O}$ from a fertilised agricultural soils, Atmos. Environ., 25A, 1961-1969, 1991.

Steudler, P.A., R.D. Bowden, J.M. Melillo, and J.D. Aber, Influence of nitrogen fertiliser on methane uptake in temperate forest soils, Nature, 34l, 314-316, 1989.
Sundström, E., and J.K. Jeglum, Five-year growth response in drained and fertilised black spruce peatlands, II Stem analysis, Ont. Inf. Rep. O-X-420, For. Can., Ont. Region, Sault Ste. Marie, 1992.

D.R. Hastie and C.L. Schiller, Chemistry Department, York University, 4700 Keele Street, North York, Ontario, M3J IP3, Canada. (email: hastie@turing.sci.yorku.ca; fs300367@sol.yorku.ca)

(Received July 5, 1995; revised April 13, 1996; accepted May 21, 1996.) 